\title{
Persepsi tentang nutrition claims, perilaku makan, dan body image antara mahasiswi kesehatan dan non-kesehatan
}

Perception of nutrition claims, food behaviors, and body images among health and non-health students

\author{
Ahmed Fahmy Arif Tsani ${ }^{1}$, Ananda Eka Astirani ${ }^{2}$, Restu Amalia ${ }^{3}$, Lisa Indraswari ${ }^{2}$, Okky Lupitasari ${ }^{4}$, Cita Ery \\ Ayuningtyas ${ }^{5}$
}

${ }^{1}$ Departemen Ilmu Gizi, Fakultas Kedokteran Universitas Diponegoro, Semarang

${ }_{2}^{2}$ Program Studi Ilmu Kesehatan Masyarakat Fakultas Kedokteran, Kesehatan Masyarakat, dan Keperawatan Universitas Gadjah Mada, Yogyakarta

${ }^{3}$ Stikes Holistik Purwakarta

${ }^{4}$ SEAMEO Regional Centre for Food and Nutrition (RECFON), Jakarta

${ }^{5}$ Prodi D4 Bisnis Jasa Makanan, Fakultas Ekonomi dan Bisnis Universitas Ahmad Dahlan, Yogyakarta

\begin{abstract}
Background: Food Marketing Institute survey results showed that $57 \%$ of consumers choose products with whole grain claims, $54 \%$ high fiber, and $53 \%$ low fat. In Indonesia, there is increasing public demand for products of low fat and high fiber. A person with a high level of knowledge, especially in those who have knowledge of health, should have a better understanding. However, it becomes difficult in transition adolescence to early adulthood period. Concern about body image to be the reason which more students choose foods that are believed to maintain the appearance remains interesting, such as on products with nutrition claims. Objective: To determine differences in perception of nutrition claims, food behaviors, and body images on health and non-health students. Method: This type of research is an observational study with cross-sectional design with two groups. The respondents were Gadjah Mada University students aged 19-24 years. Subject selection is based on consecutive sampling technique. Results: Perceptions of nutrition claims between health and non-health students differ significantly $(p=0.000)$. In both groups, the food behavior which includes the consumption of fat $(p=0.803)$ and fiber ( $p=0.926)$ did not differ, whether from food or natural products. There is no significantly difference in body image between the two groups ( $p=0.463)$. Conclusion: Between health and non-health students have different perceptions of nutrition claims, but there is no difference in food behaviours and body image between the two groups.
\end{abstract}

KEY WORDS: body image; food behavior; health students; non-health students; nutrition claims

\begin{abstract}
ABSTRAK
Latar belakang: Hasil survey Food Marketing Institute menunjukkan bahwa sebesar 57\% konsumen memilih produk dengan klaim whole grain, 54\% high fiber, dan 53\% low fat. Di Indonesia, terdapat peningkatan permintaan masyarakat terhadap produk low fat dan high fiber. Seseorang dengan tingkat pengetahuan tinggi, terutama pada mereka yang memiliki pengetahuan kesehatan, seharusnya memiliki pemahaman yang lebih baik. Namun, hal ini menjadi tidak mudah pada masa transisi remaja menuju dewasa awal. Kepedulian terhadap body image menjadi alasan mahasiswa lebih memilih makanan yang dipercaya dapat menjaga penampilannya tetap menarik, seperti pada produk dengan nutrition claims. Tujuan: Penelitian ini bertujuan untuk mengetahui perbedaan persepsi nutrition claims, perilaku makan, dan body image pada mahasiswi kesehatan dan non-kesehatan. Metode: Jenis penelitian observasional dengan rancangan cross-sectional dengan dua kelompok yang dilakukan di Kota Yogyakarta. Responden penelitian adalah mahasiswi Universitas Gadjah Mada usia 19-24 tahun. Pemilihan subjek dilakukan berdasarkan teknik consecutive sampling. Hasil: Persepsi nutrition claims antara mahasiswi kesehatan dan non-kesehatan berbeda signifikan ( $\mathrm{p}<0,01)$. Mahasiswi kesehatan mempunyai skor kepercayaan lebih tinggi daripada mahasiswi non kesehatan (46,89 vs. 45,05). Pada kedua kelompok, perilaku makan yang meliputi konsumsi lemak $(\mathrm{p}=0,803)$ dan serat $(\mathrm{p}=0,926)$ tidak berbeda, baik yang berasal dari produk makanan maupun alami. Tidak terdapat perbedaan body image secara bermakna antara kedua kelompok ( $\mathrm{p}=0,463)$. Simpulan: Mahasiswi kesehatan dan non-kesehatan memiliki perbedaan persepsi terhadap nutrition claims, tetapi tidak terdapat perbedaan perilaku makan dan body image di antara kedua kelompok.
\end{abstract}

KATA KUNCI: body image; perilaku makan; mahasiswi kesehatan; mahasiswi non-kesehatan; nutrition claims

Korespondensi: Ahmed Fahmy Arif Tsani, Departemen Ilmu Gizi, Fakultas Kedokteran Universitas Diponegoro, Jl. Dr. Sutomo No.18 Semarang, Jawa Tengah, Indonesia,e-mail: fahmi_tsani@yahoo.com 


\section{PENDAHULUAN}

Peningkatan penyakit-penyakit tidak menular dalam beberapa dekade menjadi alasan bagi masyarakat untuk lebih memperhatikan makanan yang dikonsumsi. Hal ini menjadi peluang produsen makanan untuk memproduksi berbagai makanan dan minuman yang mempunyai fungsi kesehatan bagi masyarakat, dengan cara menyantumkan nutrition claims pada label makanan sebagai daya tarik konsumen untuk penjualan produk (1). Hasil survey Food Marketing Institute menunjukkan bahwa sebesar 57\% konsumen memilih produk dengan klaim whole grain, 54\% high fiber, dan 53\% low fat (2). Di Indonesia, terdapat peningkatan permintaan masyarakat terhadap produk low fat dan high fiber.

Pengetahuan konsumen mempengaruhi keputusan konsumen dalam melakukan pembelian terhadap produk makanan dan perilaku makannya. Seseorang dengan tingkat pengetahuan tinggi, terutama pada mereka yang memiliki pengetahuan kesehatan, seharusnya memiliki pemahaman yang lebih baik. Namun, hal ini menjadi tidak mudah pada masa transisi remaja menuju dewasa awal (3). Penelitian menunjukkan tidak terdapat perbedaan yang signifikan pada perilaku makan mahasiswa kesehatan dan non-kesehatan (4).

Kepedulian terhadap body image menjadi alasan mahasiswa lebih memilih makanan yang dipercaya dapat menjaga penampilannya tetap menarik. Dengan pengetahuan yang mereka miliki dan didukung oleh gencarnya media informasi berisi produk pangan dengan nutrition claims, produk pangan low fat dan high fiber menjadi pilihan. Penelitian menunjukkan bahwa nutrition claims dapat menarik perhatian konsumen dan meningkatkan konsumsi produk yang sehat seperti makanan tinggi serat dan sereal yang diperkaya asam folat (5). Berdasarkan latar belakang tersebut dan masih terbatasnya penelitian mengenai nutrition claims di Indonesia, maka peneliti tertarik melakukan penelitian guna mengetahui perbedaan persepsi tentang nutrition claims, perilaku makan, dan body image antara mahasiswa kesehatan dan non-kesehatan.

\section{BAHAN DAN METODE}

Jenis penelitian yang digunakan adalah penelitian observasional dengan rancangan cross-sectional dengan dua kelompok. Penelitian dilakukan di Kota Yogyakarta selama bulan April - Juni 2014 dengan responden penelitian adalah mahasiswi Universitas Gadjah Mada. Pemilihan subjek dilakukan dengan teknik consecutive sampling. Pengelompokan mahasiswi dilakukan berdasarkan cluster pendidikan. Mahasiswi kesehatan terdiri dari mahasiswi Fakultas Kedokteran, Fakultas Kedokteran Gigi, dan Fakultas Farmasi. Mahasiswi non-kesehatan terdiri dari mahasiswi Fakultas Biologi, Fakultas Ekonomi, Fakultas Filsafat, Fakultas Geografi, Fakultas Hukum, Fakultas Ilmu Budaya, Fakultas Ilmu Sosial dan Ilmu Politik, Fakultas Kedokteran Hewan, Fakultas Kehutanan, Fakultas Matematika dan Ilmu Pengetahuan Alam, Fakultas Pertanian, Fakultas Peternakan, Fakultas Psikologi, Fakultas Teknik, dan Fakultas Teknologi Pertanian.

Kriteria inklusi responden yaitu mahasiswi Universitas Gadjah Mada usia 18-24 tahun, mengonsumsi produk makanan atau minuman yang memiliki nutrition claims minimal 3x dalam 1 bulan terakhir, dalam kondisi sehat, tidak dalam kondisi hamil, dan tidak sedang menjalani diet khusus. Jumlah responden penelitian sebanyak 184 orang yang terdiri dari 78 mahasiswa kesehatan dan 106 mahasiswa non-kesehatan.

Persepsi terhadap klaim kesehatan merupakan rasa percaya responden dan harapan terhadap nutrition claims yang terdapat pada kemasan produk pangan olahan. Persepsi diukur dengan mengisi kuesioner persepsi terhadap nutrition claims dengan skala pengukuran 1 sampai 5 yaitu skor 1 = sangat tidak setuju; skor $2=$ tidak setuju; skor $3=$ netral; skor $4=$ setuju; skor 5 $=$ sangat setuju. Skor hasil pengukuran dikategorikan menjadi "tidak percaya" jika skor kurang dari 17; "sedikit percaya" jika skor 17-34; "percaya" jika skor 35-48; dan “sangat percaya" jika skor lebih dari 48.

Perilaku makan merupakan hasil penilaian konsumsi makanan tinggi lemak dan tinggi serat responden per hari serta frekuensi konsumsi produk makanan dengan nutrition claims, yaitu klaim kandungan gizi (sumber serat pangan/whole grains, low fat, high fiber, fat free, zero calorie/zero sugar, non cholesterol) dan perbandingan zat gizi ( $\%$ atau g zat gizi, pengurangan trans fat, less sugar/fat, peningkatan/rich in) yang dikonsumsi responden dengan alasan tertentu. Perilaku 
makan diukur dengan metode wawancara menggunakan semi quantitative food frequency (semi quantitative FFQ). Konsumsi seluruh makanan tinggi lemak dan tinggi serat dikonversi menjadi g/hari, lalu dijumlahkan total per hari kemudian dibandingkan dengan angka kecukupan gizi (AKG).

Status gizi merupakan hasil pengukuran indeks massa tubuh (IMT) yang dihitung berdasarkan perbandingan berat badan $(\mathrm{kg})$ dengan hasil kuadrat dari tinggi badan (dalam meter). Pengukuran berat badan menggunakan timbangan digital dengan ketelitian 0,1 kg. Pengukuran tinggi badan menggunakan microtoise dengan ketelitian 0,1 cm. Pengukuran dilakukan sebanyak tiga kali untuk diambil reratanya. Status gizi perempuan dikategorikan menjadi kurang (IMT $<18,5 \mathrm{~kg} / \mathrm{m}^{2}$ ), normal $\left(18,5-22,99 \mathrm{~kg} / \mathrm{m}^{2}\right)$, dan lebih $\left(\geq 23 \mathrm{~kg} / \mathrm{m}^{2}\right)$.

Body image merupakan pikiran dan perasaan seseorang mengenai tubuhnya secara subjektif, baik dalam keadaan sadar maupun tidak sadar yang diukur dengan cara mengisi kuesioner body shape questionnaire (BSQ). Skor diperoleh dari penjumlahan keseluruhan item. Semakin tinggi nilai yang diperoleh maka semakin tinggi tingkat ketidakpuasan akan tubuh. Skor $B S Q$ diklasifikasikan menjadi empat kategori, yaitu "tidak khawatir" (skor $<81$ ); "sedikit khawatir" (skor 81-110); "khawatir" (skor 111-140); dan "sangat khawatir" (skor>140). Semua pengukuran dilakukan oleh enumerator terlatih lulusan sarjana gizi.

Analisis data menggunakan software IBM SPSS versi 20. Karakteristik responden disajikan dalam bentuk frekuensi. Perbedaan persepsi nutrition claims, perilaku makan, dan body image antara dua kelompok (mahasiswa kesehatan dan non-kesehatan) dianalisis dengan uji beda 2 kelompok tidak berpasangan $\mathrm{t}$ (t-test). Sementara analisis hubungan antara persepsi nutrition claims dengan perilaku makan dan body image pada masing-masing kelompok menggunakan uji Chi-Square.

\section{HASIL}

\section{Karakteristik responden}

Tabel 1 menunjukkan jumlah responden mahasiswi kesehatan sebanyak 78 orang $(42,4 \%)$ dan mahasiswi nonkesehatan 106 orang $(57,6 \%)$. Rerata status gizi berdasarkan nilai IMT mahasiswi kesehatan dan non-kesehatan dalam kategori normal yaitu $22,38 \mathrm{~kg} / \mathrm{m}^{2}$ dan $21,93 \mathrm{~kg} / \mathrm{m}^{2}$. Rerata persepsi mahasiswi kesehatan dan non-kesehatan terhadap nutrition claims yaitu tergolong dalam kategori percaya. Rata-rata mahasiswi kesehatan dan non-kesehatan sedikit khawatir terhadap body image.

\section{Perbedaan usia, status gizi, persepsi terhadap nutrition claims, body image, serta konsumsi lemak dan serat antara mahasisiwi kesehatan dan non-kesehatan}

Tabel 2 menunjukkan adanya perbedaan usia $(\mathrm{p}=0,014)$ dan persepsi terhadap nutrition claims $(\mathrm{p}<0,01)$ antara mahasiswi kesehatan dan non-kesehatan. Status gizi underweight dan obesitas lebih tinggi pada kelompok non-kesehatan sedangkan status gizi normal lebih banyak ditemukan pada kelompok kesehatan. Tidak terdapat perbedaan konsumsi lemak $(p=0,803)$ dan serat

Tabel 1. Karakteristik responden berdasarkan bidang studi kesehatan dan non-kesehatan

\begin{tabular}{|c|c|c|c|c|}
\hline \multirow[t]{2}{*}{ Variabel } & \multicolumn{2}{|c|}{$\begin{array}{c}\text { Kesehatan } \\
\mathrm{n}=78(42,4 \%)\end{array}$} & \multicolumn{2}{|c|}{$\begin{array}{l}\text { Non-kesehatan } \\
n=106(57,6 \%)\end{array}$} \\
\hline & Rerata (SD) & Median (min-maks) & Rerata (SD) & Median (Min-maks) \\
\hline Usia & $20,60(0,88)$ & $21,0(18-23)$ & $20,37(1,20)$ & $20,0(18-24)$ \\
\hline $\mathrm{IMT}^{1}$ & $22,38(3,03)$ & $21,9(16,6-32,6)$ & $22,18(3,82)$ & $21,9(15,3-37,6)$ \\
\hline$\%$ lemak tubuh & $28,34(3,98)$ & $28,4(18,8-38,2)$ & $27,51(4,69)$ & $27,7(17,3-41,9)$ \\
\hline Lingkar pinggang & $71,60(6,82)$ & $70,7(55,5-90,0)$ & $71,13(7,97)$ & $69,5(56-107)$ \\
\hline Lingkar panggul & $95,20(5,92)$ & $94,7(84,0-112,5)$ & $93,83(7,85)$ & $93,0(72-117)$ \\
\hline RLPP $^{2}$ & $0,75(0,05)$ & $0,8(0,6-0,9)$ & $0,75(0,04)$ & $0,8(0,68-0,91)$ \\
\hline Skor persepsi nutrition claims & $46,89(3,24)$ & $46,0(42-62)$ & $45,05(3,32)$ & $45,0(37-59)$ \\
\hline Skor BSQ ${ }^{3}$ & $92,91(27,39)$ & $88,5(45-166)$ & $90,65(28,55)$ & $90,0(37-161)$ \\
\hline
\end{tabular}

${ }^{1} \mathrm{IMT}=$ indeks massa tubuh; ${ }^{2} \mathrm{RLPP}=$ Rasio Lingkar Pinggang-Pinggul; ${ }^{3} \mathrm{BSQ}=$ body shape questionnaire; $\mathrm{SD}=$ standar deviasi; $\min =$ nilai minimal; maks = nilai maksimal 
Tabel 2. Perbedaan usia, status gizi, persepsi terhadap nutrition claims, body image, serta konsumsi lemak dan serat

\begin{tabular}{lccc}
\hline \multicolumn{1}{c}{ Variabel } & Kesehatan & Non-kesehatan & p \\
\cline { 2 - 3 } & $\mathbf{( n = 7 8 )}$ & $\mathbf{( n = 1 0 6 )}$ & $0,014^{*}$ \\
\hline Usia (tahun), median (min - maks) & $21(18-23)$ & $20(18-24)$ & \\
Status gizi, n (\%) & & & \\
$\quad$ Underweight & $3(3,85)$ & $14(13,21)$ & 0,479 \\
$\quad$ Normal & $46(58,97)$ & $54(50,94)$ & \\
$\quad$ Overweight & $15(19,23)$ & $17(16,04)$ & \\
$\quad$ Obesitas & $14(17,95)$ & $21(19,81)$ & \\
Persepsi nutrition claims, n (\%) & & & \\
$\quad$ Percaya & $59(75,64)$ & $92(86,79)$ & $0,000^{*}$ \\
$\quad$ Sangat percaya & $19(24,36)$ & $14(13,21)$ & \\
Body image, n (\%) & & & \\
$\quad$ Tidak khawatir & $28(35,90)$ & $54(42,45)$ & 0,463 \\
$\quad$ Sedikit khawatir & $31(39,74)$ & $32(30,19)$ & \\
$\quad$ Khawatir & $13(16,67)$ & $23(21,70)$ & \\
Sangat khawatir & $6(7,69)$ & $6(5,66)$ & \\
Konsumsi lemak (g), median (min-maks) & & & 0,803 \\
$\quad$ Produk & $2,82(0,01-29,82)$ & $2,54(0,00-21,00)$ & \\
$\quad$ Makanan & $26,35(10,9-98,40)$ & $28,3(12,2-100)$ & \\
Konsumsi serat (g), median (min-maks) & & & 0,926 \\
$\quad$ Produk & $1,54(0,00-16,32)$ & $1,76(0,00-16,14)$ & \\
Makanan & $4,70(1,40-38,40)$ & $4,85(0,50-35,30)$ & \\
\hline
\end{tabular}

*signifikan ( $<0,05 ;$ Mann-Whitney test)

( $\mathrm{p}=0,926)$ pada kedua kelompok, baik yang berasal dari produk makanan dan alami. Jumlah mahasiswi nonkesehatan yang tidak khawatir terhadap body image lebih banyak dibandingkan mahasiswi kesehatan. Tidak terdapat perbedaan body image secara bermakna antara dua kelompok $(\mathrm{p}=0,463)$.

\section{BAHASAN}

Status gizi mahasiswi kesehatan tidak berbeda secara signifikan dengan mahasiswi non-kesehatan, namun demikian secara deskriptif status gizi underweight dan obesitas pada kelompok non-kesehatan lebih besar dibandingkan dengan kelompok kesehatan. Hal ini dapat disebabkan oleh pengetahuan gizi yang lebih rendah dan juga kebiasaan makan yang salah. Seseorang yang memiliki pengetahuan yang baik akan mampu memilih makanan sesuai dengan kebutuhannya $(6,7)$.

Hasil uji beda persepsi nutrition claims antara mahasiswi kesehatan dan non-kesehatan menunjukkan adanya perbedaan yang signifikan. Namun, hasil ini mungkin dipengaruhi oleh jumlah responden yang tidak sama antara kedua kelompok (kelompok non-kesehatan lebih banyak dibandingkan kelompok kesehatan). Berdasarkan empat pengkategorian skor persepsi nutrition claims, skor seluruh responden berada dalam kategori "percaya" dan "sangat percaya". Hal ini menunjukan bahwa nutrition claims pada suatu produk dipersepsikan dengan baik oleh kedua kelompok mahasiswa.

Persepsi merupakan proses yang dilalui seseorang melalui tahap pemaparan, perhatian, dan pemahaman. Dengan demikian, segala sesuatu yang mempengaruhi persepsi seseorang akan mempengaruhi perilakunya. Responden penelitian yang memiliki latar belakang pendidikan gizi (kesehatan) memiliki sikap dan persepsi kesehatan lebih tinggi dibandingkan responden lain dengan latar belakang pendidikan yang berbeda, serta lebih terbiasa membaca label kemasan pangan $(8,9)$.

Berdasarkan penilaian body image, tidak terdapat perbedaan yang bermakna pada body image antara mahasiswi kesehatan dan non-kesehatan. Hanya 3,3\% responden dari masing-masing kelompok yang merasa 
khawatir terhadap bentuk tubuhnya. Hasil uji ChiSquare (data tidak ditampilkan) menunjukkan bahwa ada hubungan antara status gizi (IMT) dengan body image $(p<0,01)$. Sebesar $26,1 \%$ responden dari kedua kelompok merasa khawatir terhadap bentuk tubuhnya, proporsi terbesar adalah responden dengan status gizi obesitas diikuti dengan status gizi normal dan overweight. Hal ini sesuai dengan penelitian yang dilakukan pada mahasiswa Ilmu Kedokteran Universitas Taibah Arab Saudi tahun 2013 yang menunjukkan bahwa ada kecenderungan pada remaja dengan status gizi normal mengalami kekhawatiran terhadap bentuk tubuhnya (10).

Hasil penelitian ini juga menunjukkan bahwa tidak terdapat perbedaan perilaku makan dalam konsumsi lemak dan serat antara mahasiswi kesehatan dan nonkesehatan, baik yang berasal dari produk maupun makanan alami. Angka kecukupan gizi (AKG) untuk lemak dan serat per hari adalah $75 \mathrm{~g}$ dan $35 \mathrm{~g}$. Jika dibandingkan dengan $\mathrm{AKG}$, konsumsi responden dalam penelitian ini sangat rendah.

Hal yang menyebabkan perbedaan hasil penelitian ini dengan AKG yaitu daftar makanan dalam $S Q-F F Q$ hanya menampilkan bahan makanan sumber lemak dan sumber serat (sayur dan buah). Sementara itu, bahan makanan golongan sumber protein dan serealia tidak ikut dimasukkan dalam daftar, padahal sumber protein dan serealia juga ikut berkontribusi dalam kecukupan lemak seseorang per hari. Golongan serealia juga berkontribusi cukup tinggi dalam kecukupan serat. Responden yang terbiasa mengkonsumsi beras merah memiliki rerata konsumsi serat lebih tinggi dibandingkan responden yang tidak mengkonsumsi beras merah (data tidak ditampilkan).

Hasil penelitian ini menunjukkan tidak adanya hubungan yang bermakna antara persepsi nutrition claims dengan body image serta perilaku makan (konsumsi serat dan lemak), baik pada mahasiswi kesehatan maupun nonkesehatan. Hasil ini berbeda dengan studi sebelumnya (11) yang menunjukkan bahwa seseorang yang memiliki persepsi kesehatan yang baik, terutama pada kelompok dengan pendidikan tinggi, akan cenderung untuk memilih produk atau bahan makanan yang lebih baik.

Informasi gizi yang tertera pada kemasan memiliki peran dalam mencapai pola hidup sehat. Pengetahuan pada label kemasan juga dapat mempengaruhi kebiasaan makan sehingga diperlukan kemampuan dalam membaca, mempersepsikan, dan memahami label makanan. Informasi yang ada pada label makanan membantu konsumen dalam mengetahui komposisi makanan yang dikonsumsi. Konsumen dapat membatasi asupan kalori dan lemak dengan memahami kandungan dalam makanan. Studi kualitatif di Australia tentang nutrition claims menyebutkan tingginya kepedulian mereka pada nutrition claims produk makanan dan hal tersebut mempengaruhi keputusan mereka dalam membeli suatu produk makanan yang mereka percayai memiliki manfaat untuk tubuh mereka (12).

Keinginan untuk sehat atau untuk memiliki tubuh yang ideal seringkali menjadi alasan dalam pemilihan makanan dengan nutrition claims. Suatu penelitian dengan subjek mahasiswa menyatakan bahwa mahasiswa menggunakan label kemasan sebagai penyeleksi makanan yang efektif untuk menjaga berat badan atau bahkan menurunkan berat badan. Namun, sebagian diantaranya merasa label pada kemasan makanan tidak begitu penting karena mereka memiliki persepsi bahwa berat badannya normal sehingga tidak perlu khawatir terhadap kandungan gizi dalam makanan yang dikonsumsi (13).

\section{SIMPULAN DAN SARAN}

Rerata status gizi berdasarkan nilai IMT mahasiswi kesehatan dan non-kesehatan dalam kategori normal. Terdapat perbedaan persepsi terhadap nutrition claims antara mahasiswi kesehatan dan non-kesehatan, tetapi tidak terdapat perbedaan konsumsi lemak dan serat, status gizi, serta body image di antara kedua kelompok. Rerata konsumsi lemak dan serat yang berasal dari makanan lebih tinggi dibandingkan dengan yang berasal dari produk makanan dan minuman. Mahasiswi nonkesehatan cenderung tidak khawatir terhadap body image dibandingkan dengan mahasiswi kesehatan. Tidak terdapat hubungan antara persepsi nutrition claims dengan body image dan konsumsi lemak dan serat.

Penilaian body image pada responden dengan status gizi yang bervariasi (underweight, normal, overweight, dan obesitas) sebaiknya tidak hanya menggunakan satu kuesioner. Body shape questionnaire (BSQ) dapat digunakan dengan kuesioner lain yang 
reliable jika digunakan pada responden dengan status gizi underweight. Penggunaan FFQ untuk menilai konsumsi serat dan lemak selama satu bulan terakhir dapat didukung dengan data recall 24 jam sebagai pembanding hasil untuk menghindari adanya bias. Penelitian kualitatif dengan metode indepth interview dapat dilakukan untuk mengetahui alasan responden mengonsumsi produk makanan atau minuman dengan nutrition claims.

\section{Pernyataan konflik kepentingan}

Tidak ada konflik kepentingan dalam penelitian ini.

\section{RUJUKAN}

1. Assema PV, Glanz K, Brug J, Kok G. Effect of health claims on eating habits of the Dutch population. European Journal of Public Health 1996;6(4):281-7.

2. Diary Council Digest. Understanding nutrition claims on food labels. Diary Council Digest 2007;8(1).

3. Deliens T, Clarys P, De Bourdeaudhuij I, Deforche B. Determinants of eating behaviour in university students: a qualitative study using focus group discussions. BMC Public Health 2014;14(53).

4. Tirodimos I, Georgouviai, Savvala TN, Karanika E, Noukari D. Healthy lifestyle habits among Greek university students: differences by sex and faculty of study. East Mediterr Healt J 2009;15(3):722-8.
5. Williams PG. Can health claims for foods helps consumers choose better diets?. Clinical Nutrition Remedica Journal 2006;15(2):25-30.

6. Permaesih. Status gizi remaja dan faktor-faktor yang mempengaruhi. [series online] 2003 [cited 2014 Jan 29]. Available from: URL: http://digilib.litbang.depkes.go.id

7. Emilia E. Pengetahuan, sikap, dan praktik gizi pada dewasa dan implikasinya pada sosialisasi perilaku hidup sehat. Media Pendidikan, Gizi, dan Kuliner 2009;1(1):1-10.

8. Misra R. Knowledge, attitudes, and label use among college students. J Am Diet Assoc 2007;107(12):2130-4.

9. Kom L, Gonen E, Shaked Y, Golan M. Health perceptions, self and body image, physical activity and nutrition among undergraduate students in Israel. PLoS ONE 2013;8(3):e58543.

10. As-Sa'edi E, Sheerah S, Al-Ayoubi R, Al-Jehani A, Tajaddin W, Habeeb H. Body image dissatisfaction: prevalence and relation to body mass index among female medical students in Taibah University. Journal of Taibah University Medical Sciences 2013;8(2):126-33.

11. Ruspriana D. Konsumsi dan persepsi manfaat minuman probiotik pada remaja putri [Skripsi]. Bogor: Institut Pertanian Bogor; 2008.

12. Chan C, Patch C, Williams P. Australian consumers are sceptical about but influenced by claims about fat on food labels. Eur J Clin Nutr 2005;59:148-51.

13. Rasberry CN, Chaney BH, Housman JM, Misra R, Paula JM. Determinants of nutirition label use among college students. Am J Health Edu 2007;38(2):76-82. 